\title{
Cellular Cast Measurement
}

National Cancer Institute

\section{Source}

National Cancer Institute. Cellular Cast Measurement. NCI Thesaurus. Code C74764.

The determination of the amount of cellular casts present in a urine sample. 